\title{
PREVAILING IN A WELL-ARMED WORLD: DEVISING COMPETITIVE STRATEGIES AGAINST WEAPONS PROLIFERATION
}

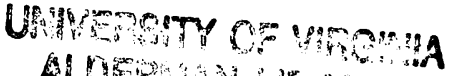

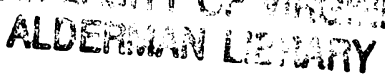 \\ MAY 252000

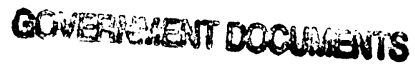 \\ Nod Ex
}

Henry D. Sokolski

Executive Director

Nonproliferation Policy Education Center

Editor

March 2000 